Please do not remove this page

RMIT

UNIVERSITY

\title{
Re-reengineering the dream: agility as competitive adaptability
}

McLay, Allan

https://researchrepository.rmit.edu.au/esploro/outputs/9921859439901341/filesAndLinks?institution=61RMIT_INST\&index=null

McLay, A. (2014). Re-reengineering the dream: agility as competitive adaptability. International Journal of Agile Systems and Management, 7(2), 101-115. https://doi.org/10.1504/IJASM.2014.061430

Document Version: Accepted Manuscript

Published Version: https://doi.org/10.1504/IJASM.2014.061430

Repository homepage: https://researchrepository.rmit.edu.au

(c) 2014 Inderscience Enterprises Ltd.

Downloaded On 2023/04/27 00:14:48 +1000

Please do not remove this page 
Thank you for downloading this document from the RMIT Research Repository.

The RMIT Research Repository is an open access database showcasing the research outputs of RMIT University researchers.

RMIT Research Repository: http://researchbank.rmit.edu.au

\section{Citation:}

McLay, A 2014, 'Re-reengineering the dream: agility as competitive adaptability', International Journal of Agile Systems and Management, vol. 7, no. 2, pp. 101-115.

See this record in the RMIT Research Repository at: https://researchbank.rmit.edu.au/view/rmit:27775

Version: Accepted Manuscript

Copyright Statement: (c) 2014 Inderscience Enterprises Ltd.

Link to Published Version:

http://dx.doi.org/10.1504/IJASM.2014.061430 
Re-Reengineering the Dream: Agility as Competitive Adaptability

\author{
Allan McLay \\ allan.mclay@rmit.edu.au
}

RMIT University

School of Aerospace, Mechanical \& Manufacturing Engineering

LaTrobe Street

Melbourne, Victoria 3000

Australia

Over the past 20 years, the author has been Program Director for the Master of Engineering (Engineering Management) and Master of Engineering (Quality Management) programs in the School of Aerospace, Mechanical \& Manufacturing Engineering at RMIT University, and previously Course Leader and Acting Head of School, Graduate School of Engineering, RMIT. Prior activity included 12 years in the TAFE Off Campus Coordinating Authority as Manager Telematics, responsible for the introduction of satellite and terrestrial videoconferencing delivery for distance-mode vocational education in Australia and subsequent development of early online education delivery systems. 


\title{
Re-Reengineering the Dream: Agility as Competitive Adaptability
}

\author{
Abstract \\ Organizational adaptation and transformative change management in \\ technology-based organizations is explored in the context of collaborative \\ alliances. A Re-reengineering approach is outlined in which a new Competitive \\ Adaptability Five-Influences Analysis approach under conditions of collaborative \\ alliance, is described as an alternative to Porter's Five-Forces Competitive \\ Rivalry Analysis model.
}

\section{Keywords}

Adaptability, competition, collaboration, disruptive technological change, reengineering, paradigm change, manufacturing.

\section{Introduction and the Problem Expressed}

The onset of the industrial age brought with it a significant shift in the range and level of skills and expertise required to design, develop and produce products of all kinds. The earlier individualistic artisan skills passed down through the ages from master to apprentice became increasingly irrelevant in the rush to manufacture en-masse. However, this very same displacement of the earlier artisan in turn led to a new form of master-apprentice relationship, a more mechanistic version largely premised on and formulated by the form and function of extant technology, rather than an adjustable continuum of established skills and expertise. This new age put in place a continually rolling and ever changing expectation for 'new technology' and its associated set of specific technology focussed skills and expertise as core corporate competencies (Hamel \& Prahalad, 1990).

Whilst continuous change in technology and the associated effects of technology shock (Dedola \& Neri, 2006; Christiano, Eichenbaum \& Vigfusson, 2003) are not new constructs, the reality of the industrial age was and is a continuing reduction in timeline for relevance and lifetime for a specific technology and the related skills and expertise base required for its effective implementation. This, combined with increasing pressures for innovation (Tidd \& Bessant, 2013) and at times severe impacts from both local and global economic environments (Hitt, Ireland \& Hoskisson, 2011) raises serious challenges for contemporary management teams seeking to strategically position a company and its technology base advantageously, relative to its suppliers, competitors and customers, as well as in predictive readiness for future technological change and opportunistic adaptation.

In effect, the life-cycle of a technology has become typically one of disruptive change and rapid adjustment, followed by a plateau as a particular technology or process captures and holds its position against minor challenges, eventually to be displaced by yet another alternative (Bower \& Christensen, 1995). The 
continuing introduction of new engineering processes and smarter technology has in turn demanded more rapid response times across supply chains feeding continuing globalisation of industrial and commercial business. Over time, this has inexorably led to a technology life-cycle that exhibits embedded disruption, rapid diffusion, increasing knowledge intensity, and a decreasing timeline from onset to demise and displacement, classic forms of Schumpeter's 'creative destruction' (Schumpeter, 1950) and Christensen's concept of 'disruptive innovation' (Christensen, 1997). The impact of such changing life-cycles can also be seen in the expanding array of product generations, with seemingly perpetual updates (a form of response to diffusion and increasing knowledge intensity) and the changing face of contemporary business models over the past decade.

Today, these changes are reflected in demand for the new artisan skills of IT consciousness, social networking capabilities and presence, and in science and technology quarters, an increasing need to capture and apply breakthrough science in shrinking time-scales. Whilst the world may seem a smaller place thanks to intelligent global network services and a plethora of smart IT and communications technology devices and social-media, the underlying reality is that it still takes time to conceive, design, develop, produce, commercialise and globalise a new technology, by which time it is already facing displacement! Such is the problem facing contemporary business and technology based organisations per se, in attempts to continually reengineer corporate and technology processes (Champy, 1995) in the face of continuing and at times seriously aggressive innovation and disruptive technological, operational, and process change (Hitt et al, 2011; Tidd \& Bessant, 2013; White \& Bessant, 2007). However, simply moving the corporate and production engineering deckchairs in an apparently perpetual dance does not in itself resolve such. It is here argued that continuing disruptive technological change necessitates radical revolutionary approaches by management to developing a more agile industrial sector and technologically potent economy.

\section{Case Study: Factories of the Future in the European Union}

In an exemplar (macro-level) approach to addressing the need for radical change and adaptation across industrial sectors, the European Union has taken up the challenge of moving European manufacturing industries into the 'digital futures' environment as a matter of urgency and with a particular emphasis on small and medium enterprises (SME's). The manufacturing sector is a significant component in the European Union's overall economy, representing $21 \%$ of the European Union's GDP and 20\% of the European Union's employment (Wray (2012). In recent years, the manufacturing and technology-based industry sectors across the European Union have suffered serious and continuing competition from Eastern Europe, North and South Asia, Africa and South America based manufacturers able to source low-cost labour and production technology. Collectively, these international competitors form a bloc commonly referred to as the BRICS countries or economies, specifically: Brazil, Russia, India, China, and South Africa (Fifth BRICS Summit, 2013; Wray, 2012). In response, the European Commission has outlined a clear intention to restructure and re-enervate advanced manufacturing industries across the European Union as a key enabler strategy for re-establishing European industrial leadership and economic competitiveness (Beernaert, 2012). 
The European Commission has actioned this strategy in collaboration with European industry, through funding $€ 1.2$ billion across $2010-2013$ for PublicPrivate-Project research targeted at producing a mix of new technological fixes to long-standing (and increasing) systemic areas of concern affecting global competitiveness for the European Union's industrial manufacturing sector (European Commission, 2012). In summary these areas of concern reflect a need to redress the embedded affects resulting from long term evolution of: closed thinking, restrictive practices, resource-based decision making (for example: production techniques based only on access to low cost labour), and failure to pro-actively move toward a more service-oriented and knowledge driven economic environment and new organisational and informational architectures (Beernaert, 2012).

The diverse nature of these areas of concern underwrites the complexity of identifying and addressing the many issues that confront organisations undergoing or facing a future of significant technological paradigmatic transition (Dosi, 1982; Geels, 2005). In effect, the European Commission is preparing organisations across the European Union for transition to innovative and collaborative decision-making environments, as digital-assets-intense enterprises operating in digital factory environments (European Commission, 2012). This will necessitate adapting systems, processes, procedures, organisational and structural relationships, whilst acquiring new technological skills and building new corporate competencies (Hamel \& Prahalad, 1990, 1994). In particular, there will be a further emphasis for radical-revolutionary change across all aspects of manufacturing. This will be particularly so in the use of state-of-the-art information and communications technology (ICT), simulations systems, adaptive robotic manufacturing systems, and the introduction of new materials, products and services. This is perceived by the European Commission as an essential condition for future growth and success in its manufacturing sector (European Commission, 2012). This response by the European Union provides a unique opportunity to observe a major industry sector faced with the prospect of actioning extensive innovation and technological change or face inevitable demise.

Whilst long overdue and necessarily a long-term strategic planning approach, the above European Union example of industry-wide transition is presented as that of a deterministic technology-driven or 'technology push' paradigm (in this case clearly a form of cybernetic determinism with its push for increasing complexity in technology base, particularly with regard to information and communications technology systems) plus a significant element of 'market pull' (as a form of naive expectancy, where the commercial requirement for technological change is seen as being in response to a growing demand or explicitly defined need)

(Cetindamar, Phaal \& Probert, 2010). In this regard, it appears that European Commission researchers have also made, at least in part, the essential connection between the technological imperative paradigm and the critical causal and affective socio-technical influences of the social structures and related human factors elements (Geels \& Schot, 2007). These will become critical to successful collaboration across multiple organizations and their array of technology platforms, infrastructures, organisational cultures, skills, competencies, knowledge management, communities of practice, policies, 
product specific processes, Quality and service orientation (Coakes \& Clarke, 2011).

The performance of European organisations undergoing such transitions and the engineering, technological, and knowledge management issues identified, are also directly relevant to future (and inevitable) such transitions across the global manufacturing sector. This was recently highlighted in the Australian manufacturing context in the release of the following two government instituted reports: A report to the Victorian State Government Minister for Manufacturing, Exports and Trade, 'A More Competitive Manufacturing Industry, New Directions for Industry Policy and Manufacturing' (Department of Business and Innovation, 2011); and a report to the Federal Minister for Industry and Innovation, 'A Report from the Prime Minister's Manufacturing Taskforce' (DIISRTE, 2012). Among its many recommendations it specifically addresses urgently targeting adaptation of the Australian manufacturing sector to ensure future competitiveness and performance in the face of continuing global economic and technological change (DIISRTE, 2012).

\section{The Case for Re-Reengineering}

Whether or not European Union based organizations engaged in the Factories of the Future Public-Private-Projects, or Australian manufacturing enterprises, have demonstrated a new way of looking at, thinking about, and using technology and knowledge based systems, products, processes, and services, remains to be seen. Similarly, whether or not their experience in instituting (inevitable) sectorwide disruptive paradigmatic change can inform further adaptation in related industry sectors, must await both time and the evidence of observable outcomes. However, it is certainly possible to reflect on past experiences in wide-spread reengineering approaches to identify and apply associated theoretical perspectives to potential opportunities for adaptation and change in the current context.

It matters little if a company is in Western or Eastern Europe, in the South Pacific, the Americas (North or South), the middle-East or South, or a rising 'dragon' of greater Asia, the time approaches when industrial and business organisations alike must needs re-think, re-formulate, and effectively rereengineer organisational form, function, and process. In a different Age, Scottish social philosopher and pioneer political economist Adam Smith, incorporated into his seminal work 'The Wealth of Nations' (circa 1776) a focus on individual skills and the division of labour as a basic paradigm for an effective industrial economy. A stratagem taken up by Twentieth Century governments of developed industrial economies and their educational providers alike, to be reinterpreted as a focus on development of vocational task-based 'skills' and skillsbased 'competencies' as central elements in national agenda for sustainable economic success. Smith is likely to have agreed and disagreed, all at the same time!

The increasing displacement of basic skills-based competencies across contemporary developed economies in favour of more 'knowledge-based' skills and competencies (Trappey \& Trappey, 2010) is strongly challenging the fundamental basis of Smith's paradigm as so commonly interpreted. For example, the latter decades of the Twentieth Century saw a number of artisan and production process-based activities outsourced to developing country 
locations, a system whereby increasing labour costs in developed economies were offset by lower costs elsewhere. Where artisan styled skills are still commonly applied, as is often the case in developing economies, they are primarily focussed on specific task-based activities in product design, production processes, or other explicitly defined areas of 'trained' behaviour. Whereas, a knowledge-based economy invokes a new approach that expresses not only understandings of what is required and access to resources (including development, acquisition of, or access to relevant technology base) but also an advanced capacity to plan, create, implement and manage potentially disruptive processes (Hitt et al, 2011;Christensen \& Raynor, 2003) that can strategically position a company (or nation for that matter) to capture and sustain market position (Johnson, Scholes, \& Whittington, 2011).

In the early 1990's, Hammer and Champy (1993) and subsequently Champy (1995) and Hammer (1996) endeavoured to replace earlier attempts at reconceiving the form and function of organisational structures with a new emphasis towards understanding the processes that underpin industrial systems and business operations. Their approach entailed a radical redesign of business processes using the concept of 'business process reengineering' (BPR). Implicit in their construct of reengineering of contemporary industrial and business enterprises was the willingness and capability of an organisation to face endemic challenges and embrace radical change. Some future focussed enterprises could and did, whilst others might have but did not. Curiously, some who could and did, did not subsequently survive, whilst conversely, others who could not and did not, did survive! Hammer and Champy's (1993) concept of reengineering was built on a construct of re-building and the literal re-booting of a company's operational systems to envisage a virtual re-birthing of the enterprise, a classic vision of the re-birthed Phoenix rising from the ashes of its former self.

Two decades later, post global financial crisis and the meltdown of government industrial policies, the demolition, dissolution, or rescue of major banking institutions, and the disappearance of multiple industrial and business corporations around the globe, industry and business face new challenges that again demand a radical shift in thinking and change in approach. Just as earlier reengineering approaches envisaged the 're-birthing' of an organisation, so also may we consider the potential for such occurrences in the current European Union and Australian manufacturing contexts, only at a much broader industry sector level. Hammer and Champy's (1993) earlier model envisaged the organisation or enterprise largely as a bounded entity where the focus of the reengineering exercise was essentially to re-structure the organisation from the level of its products and processes upwards. Get the process and its relationships with other processes right and the organisational structure and its required technology-base would logically follow. Applying 'Systems Thinking' approaches to this (Checkland, 1999) it can be seen that identifying relationships and the connectedness or linkages between both corporate and technological processes, was a key element in the business of reengineering the 1990's organisation.

As an exemplar of twenty-first century thinking, the more recent European Commission analysis of manufacturing enterprises undertaken at industry sector level across the European Union (European Commission, 2012) clearly requires 
a more macro level approach, referred to here as: Re-reengineering. Although still addressing the driving forces that engendered the original reengineering approach, Re-reengineering must now take the response well beyond the boundaries of the individual organization and its bounded set of products, processes, approach to design, production planning and technology base. Shifting thinking beyond the limitations of the individual enterprise both raises inherent barriers and extends opportunities for adaptation and fundamental change. It also raises the potential to consider a more integrated (disruptive, yet less destructive) approach to the induction of paradigmatic change at both the individual enterprise and industry-wide levels.

Just as Hammer and Champy's (1993) earlier approach focused on the efficacy of the individual enterprise to understand it's product and service processes needs, so also must a new Re-reengineering approach address and facilitate renewal in the individual enterprise, whilst doing so in a manner that also facilitates renewal in the external industry sector and it's commercial, technological and social environment. The European Union experience to date indicates that where shifts or new adaptations to current technological practice in an individual enterprise may provide initial or short-term competitive advantage, it is only through integration of such new practices across industry sectors that more broadly based and sustainable benefits can be achieved (European Commission, 2012).

In effect, developing informed 'communities of practice' (Hernáez \& Campos, 2011) and enterprise-to-enterprise (including cross-sector) collaborative environments provides opportunity for value adding benefits, to the individual organization, its suppliers and customers, and the wider industry sector (Coakes, \& Clarke, 2011). A strategy premised on leveraging sector-wide performance enhancement, rather than a narrow approach creating bounded 'silos' of constrained access to new thematics and practice and focused only on the shortterm development and wishful sustainment of competitive rivalry (Lencioni, 2006). In turn, it evokes a strategy that replaces the short-term benefit of 'outsourcing' production to low-cost sources, in order to focus more on creating inter-enterprise and cross-sector knowledge, skills and competencies that enable the development of smarter, more creative and adaptable design and production systems.

\section{The Case for Alternative Metrics}

This alternative approach challenges both Hammer and Champy's (1993) narrow focus on the individual corporation, and potentially brings an alternative metric into the classic regime of strategic business analysis instruments. Porter's FiveForces analysis approach to building business strategy (Porter, 1980) through understanding the forces that impact on the enterprise, has been a dominant analysis tool across business and industry for three decades, with it's centrality on determining and building 'competitive rivalry' as a premier determinant of success (Johnson et al, 2011). (See Figure 1).

Porter's approach hinges on factoring in the influence of the four core elements that he perceived as critical to determining a measure of an enterprise's 'Competitive Rivalry': the 'Threat' posed by potential new entrants; the 'Threat' posed by either existing or new substitutes; the 'Bargaining Power' of suppliers in the up-stream supply chain; and the 'Bargaining Power' of buyers and customers 
(Porter, 1980). Collectively, both the intuitive perceptions and inferences arising from the language and suggested locus of associations being used in the analysis of these four core elements, invoke aggressive positioning relative to the fifth element as a measure of 'Competitive Rivalry'. In effect, Porter's legacy has been that of a self-perpetuating logic of aggressively competitive rivalry.

\section{INSERT FIGURE 1 ABOUT HERE}

In an industrial post global-economic-crisis environment, survival of the strongest and fittest, as typified by aggressive hyper-competitive rivalry (D'Aveni \& Gunther, 1995) and rigorous pursuit of sustainable competitive advantage (Porter, 1979) is not necessarily the same as survival capacity for the agile, adaptive-collaborative capable enterprise (McGrath, 2013; Nalebuff \& Brandenburger, 1997). It is argued that, 'Competitive Adaptability' may well be an alternative metric for Porter's 'Competitive Rivalry', or potentially the premise on which a whole new Competitive Adaptability Analysis approach could be developed. In retrospect, Toffler (1985) identified the need for this potential shift when he referred to the then (and potentially still 'as now') domination of market sectors by 'corporate dinosaurs', commercial and industrial organizations exhibiting limited capability for adaptation to meet a changing environment.

Where historically, individual fortunes have been made opportunistically riding on the back of economic turbulence, here we see the potential for the manufacturing sector in the European Union, and in Australia, to both ride out the turbulence and in the process formulate a new form and structure for industrial relationships and the building in of adaptability as a core corporate competency. The following diagram (see Figure 2) provides an outline of a possible parallel analysis approach to that of Porter, here focused on causal influences on adaptability/agility of an organization rather than Porter's more aggressive elements of bargaining 'power' and 'threats' of entrants and substitutes (Porter, 1980). The emphasis here is more on identifying 'performance' related issues and an ability to manage an effective response to external influences through developing a capability for collaboration and adaptation.

\section{INSERT FIGURE 2 ABOUT HERE}

In considering how this 'Five -Influences Competitive Adaptability Analysis' model may be applied in the case of the European Union Factories of the Future collaborative Private-Public-Projects, it is clear that future implementation strategies should take cognizance of the strategic positioning and sociological 
aspects of contemporary manufacturing oriented organizations and their connection to the market context in which they are operating (Johnson et al, 2011). In particular, there is the need to appraise the potential impact of radical or disruptive new technology influences capable of inducing Kuhnian paradigmatic change (Kuhn, 1962; Turnbull, 1991) or Gestalt switch like shifts, or Constant's style technological revolution capable of inducing strategic discontinuity or' technology shock' (Arnold, 2003; Constant, 1984; Tidd \& Bessant, 2013) in an enterprise's knowledge, competencies, and underlying technology and applications base, regardless of the direction or source of such influence (Dedola \& Neri, 2006; Christiano, 2003).

Similarly, consideration should be given to determining the potential for strategically inducing such shifts. Such consideration could further provide a means of identifying core competencies and strategically relevant capabilities that enable enterprises to actively and effectively engage in the transitions proposed in the Public-Private-Projects approach. It can be further argued that enterprises already skilled in the development and application of effective innovation and change management practices are most likely to find this model already reflecting their established modus operandi.

If for example, knowledge assets are to be a significant component in the application of new technology and process change, then it will be essential that effective knowledge creation strategies, knowledge based tools for process design and planning, and innovative methods for knowledge capturing and knowledge re-use, are both available to management and are adequately resourced and maintained throughout the involved organization(s) (Nonaka \& Teece, 2001). This for example could be through identifying the locus or source of such knowledge, ascertaining and evaluating its potential value-adding capability to the organization, and subsequently its targeted internal distribution throughout collaborating organizations. It will also be necessary that the role of knowledge management as a socio-technical function is clearly understood and agreed on by management (whether executive or line-based) and supported effectively (Coakes,2002). This is particularly so in relation to ensuring appropriate risk mitigation strategies are in place in the planning, creating and implementing of new and potentially disruptive technologies and the strategically critical area of supporting effective decision making.

A Re-reengineering approach should also endeavour to identify whether intensive review of the individual enterprise's technological knowledge, skills, and expertise prior to actioning the introduction of what can best be described as radical approach to the widespread diffusion of disruptive innovation, can lead to reduced embedded risks of potentially calamitous outcomes at the level of individual organizations. It is not so much that the new science and subsequent applied technologies proposed to be developed and/or introduced will fail, rather that many of the organizations attempting to implement them may effectively implode, or their internal social structures collapse in disarray. Such is the potential outcome for unsuccessful transition from an old and established technology base and mode of operations, to a new radical and disruptive technology, driven by paradigmatic change. 
It is essential that successful transitioning strategies be identified and taken into account in order to maintain balance between seemingly competing domains of influence and practice (Geels \& Schot, 2007). Fundamental among these issues is the need to identify and integrate corporate core competencies in the areas of: knowledge, skills and expertise related to the introduction of advanced new technological tools; information and knowledge management strategies and processes; the characterization and assembly of coherent data-sets; and the detailed modelling of enterprise functions and related activities, resources and supply-chains (Tidd \& Bessant, 2013). The introduction of radical and potentially disruptive innovation across multiple partnerships and alliances as proposed in the European Union's Digital Factories projects may well provide a context for successful integrative knowledge management, as an instrument for change in future decision-making. It may also have the significant advantage of providing the prepared and competent user/organization with insights into the enterprise's information and knowledge management assets not hitherto easily available.

It is notable that in the current European Union's Digital Factories regime, collaboration processes are largely structured around 'project' based alliances, where the evolution of transformative change is seen as the central purpose of the alliance/collaboration. Typically, there are 10-12 (and in one instance 19) organisations engaged in each of the 26 ICT focussed projects. These have attracted to date a total of $€ 115$ million in public funding, following the first two 'Calls for Proposals' under the ICT part of the Factories of the Future and initiated through 2010- 2012. Altogether, 26 major projects involving at least 239 Organisations distributed across 21 countries and with at least 17 such organisations involved across multiple projects (European Commission, 2012). Collectively, a significant and possibly unique opportunity to observe a range of collaborative alliances collectively engaged in transformative change and the strategic repositioning of a major, internationally focussed, industry sector.

What then are the critical areas of performance that could affect organizational adaptation, change, and agility in such intensely focussed projects and alliances and how may they be measured? Similarly, what are the critical organizational parameters that are impacted on by transition to collaborative/adaptive engagement? In order to address these issues we can use existing theory, practice and understandings in strategic management, innovation and change management, and organizational theory and practice. Five specific and convergent concepts derived from these theoretical regimes immediately arise: the achievement and sustainability of critical mass; clarification of economies and diseconomies of scale; identification and attribution of critical success factors; an explicit focus on value creation; and an embracing of adaptation and change as a cultural norm. If collaborative alliances are to genuinely institute conditions for transformative paradigmatic change, not just within individual enterprises but across an industry sector, then these five concepts must be addressed and their relationships and linkages understood.

The first two of these concepts, critical mass and economies and diseconomies of scale are commonly misunderstood or confused with each other. In the context of the European Union's collaborative Public-Private-Project activities, economies of scale can be seen in the potential to invest in developmental and strategic research activity that could only be economically achieved through the sharing of resources and bringing together of an extended breadth and scale of 
knowledge, expertise, and technological resources. At the same time there is also the risk of 'over-extending' such scale of activity, triggering a reduction in efficiency and reduced overall performance and thus a form of diseconomy of scale. Typically, such negative results can be seen where the dimension or scale of communications required to maintain progress becomes excessive and starts to breakdown or be disruptive. Similarly, where the 'cost of association' between players in large alliances or aggregated collaborations becomes prohibitive, then the onset of diseconomy of scale can be expected (Johnson et al, 2011). The message here is: beware thinking that more is necessarily better. The concept of critical mass is more complex to define in the context of collaborative/adaptive alliance building. In general, critical mass refers to a set of conditions which, when reached, enables a self sustaining continuum or at the very least a predictable response that can be sustained provided the critical mass conditions are maintained (Rogers, 2003). It is this latter interpretation that is likely most relevant to organizational contexts. Even so, it is difficult to envisage a common set of conditions that would apply across the European Union's collaborative Public-Private-Project activities or any similar range of industry engagements. However, a possible contender for critical mass would be to consider the required level of explicit knowledge, skills, expertise and technological resources to enable or initiate the entry conditions for an economy of scale.

In turn, there is the interesting prospect of an inverted outcome relative to economy of scale. In an economy of scale relationship the initial entry costs may be high but then rapidly diminish with increasing scale of operations or through extended applications of the innovation being developed or trialled, whereas the sustainment level of critical mass for available skills and expertise is more likely to be a rising curve against the maturity of the innovation. This presents the issue of creating a potentially increasing critical mass of required skills and expertise as both barrier of entry to new entrants or competitors (under a Porter's Five-Forces analysis approach) and an increasing requirement for growth in skills and expertise for sustainment by the existing players!

Association, relationships and linkages are essential components in establishing an effective collaboration or alliance between otherwise potentially competing, or disassociated organisations. However, for the collaboration to continue (an inherent outcome of the critical mass concept) then it appears that the individual players/organizations need to either collectively grow their knowledge base, skills, expertise, and access to required technology (the very areas which initially brought them together) or to adapt business models and strategic positioning modalities to maintain a shared access to the new critical mass levels of knowledge, skills, expertise and technology. Clearly this raises serious questions about the long-term sustainability of collaborative ventures outside of extremely narrowly focussed ventures requiring unique combinations of knowledge, skills, expertise and technology base.

Ascribing critical success factors against collaborative alliances raises multiple possible, and potentially measurable, parameters that inherently reflect strategic capability for adaptation and organizational agility. It also requires consideration of the strategic dynamics in play and strategic capabilities (Johnson et al, 2011) not just at individual enterprise level but also in the broader industry at the level of national and international economic environments, and the potential to create 
and engage in new market spaces or 'Blue Ocean' environments (Kim \& Mauborgne, 2004, 2005). Identifying those collective areas of knowledge, skills and expertise that already exist and are currently ascribed as strategic capabilities or significant components supporting an enterprise's competitive position, only partly addresses the construction of critical success factors in a collaborative alliance environment such as envisaged in the European Union's 'futures' view. It is here that classic 'multiplicity' factors in the accumulative effects of adding multiple high level skills has the potential to impact positively, whilst the prospect of culture clash between collaborating organizations has potential for negative impact. Similarly, an established market acceptance for one company's products and services, or 'brand' name, may not necessarily transfer to a new collaborative alliance.

Both Porter's (1985) 'differentiation' and Kim and Mauborgne's $(2004,2005)$ Blue Ocean analysis are of particular interest in attempting to identify potential areas for generic critical success factors across potentially adaptable collaborative alliances such as proposed in the Factories of the Future projects. Porter primarily identified three drivers for creating competitive advantage: Cost, as an element that can for example be driven down through management of economy of scale; Differentiation, where specific products or services carry a level of perceived value and performance that sets them ahead of competitors; and Focus, for example where a company specialises and builds a niche market or product range that is extremely difficult for competitors to imitate or effectively compete against (Hitt et al, 2011). Kim and Mauborgne's Blue Ocean strategy effectively uses this concept of creating a strategic gap between products and services of otherwise competing companies that in turn creates seemingly still waters that run deep, the concept of an uncontested market space. Products and services for which there is, at least at present no viable alternative or competitor.

The alternative view, or Red Ocean strategy, is that of where competing products and services are driven down in market 'price' to the point where cost of production equals or is greater than market price. A condition that faces many goods currently manufactured across the European Union, North American and Australasian nations. Interestingly, Kim and Mauborgne also argue that it is from the experience of operating within the turbulence of this Red Ocean environment that enterprises are able to create the opportunity to adapt and transform products, services and even the marketplace itself to affect a new Blue Ocean environment. This implies moving out of the aggressive and destructive influence of competitive move and counter-move and the debilitating under-tow current of competitive cycles to create a region of new market space. "To win in the future, companies must stop competing with each other. The only way to beat the competition is to stop trying to beat the competition... Although some blue oceans are created well beyond existing industry boundaries, most are created from within red oceans by expanding existing industry boundaries. In blue oceans, competition is irrelevant because the rules of the game are waiting to be set" (Kim \& Mauborgne, 2005, p. 4-5). Whilst subject to at least a degree of professional scepticism and contrary to much accepted academic business theory and the realities of commercial practice, this viewpoint expounds an entirely new paradigm in commercial practice that in fact reflects exactly the conditions facing much of Western European, American, and Australasian manufacturing industry. Not simply a new way of moving forward, but an 
acknowledgement that existing knowledge, skills, expertise and technological prowess, can leverage adaptation and change in ways that create entirely new value opportunities in uncontested market space and that breaks the traditional nexus with existing market competition, competitors, and established technology base.

How then to determine, let alone measure, generic critical success factors for a new manufacturing sector strategy based on wide-spread collaboration and adaptability. The following three areas of interest would appear to encompass a possible Blue Ocean-like approach, each with an inherent range of measurable characteristics. Access to additive knowledge, skills and expertise, technology, and product and process design capabilities; development of non-imitative newtechnology, materials, processes, products and value-adding services; and a distinctive 'futures' market focus.

\section{Conclusions}

A focus on the creation of future new market space for products and services provides a powerful engine for innovation and change. Without this focus on adaptation no company is likely to formulate a Blue Ocean strategy other than by accident! Agility at the level of corporate and executive leadership in strategy formulation and the tactical allocation of resources to leverage strategic repositioning is an essential characteristic and key critical success factor that unlocks the resources of the enterprise and focuses them on addressing new market space. In the context of a Re-reengineering approach to building collaborative alliances, this in turn places a focus on identifying the elements of knowledge, skills, expertise (particularly in product and process design capability), technology (as required to achieve or leverage a Blue Ocean style strategy), and opportunity for new or re-vitalised products and services. Where existing core corporate capabilities and competencies within the organisation do not meet these requirements, or inhibitive quantum limitations exist on the availability of such, then a collaborative approach that gives access to new resources that add to the existing knowledge and skills base (potentially a form of transferring of core competencies as intangible resources) can potentially induce the necessary conditions for Blue Ocean style strategy development and paradigm change.

Implicit in this analysis is the expectation that corporate and executive leadership focuses on ensuring an enduring resilience within the organisation, and a capacity for learning and adaptation as new ideas, concepts, knowledge and skills are introduced. There is in turn an explicit focus on value creation and an embracing of adaptation and change as a cultural norm.

In the world of twenty first century management, flexibility and potential for adaptation is a characteristic that differentiates the adaptable knowledge focussed learning organization from the corporate dinosaurs of Alvin Toffler's pre dot-com world, transformative organizations that continually adapt, adopt, and renew, as and when required. This reflects a very different notion of industrial or technological 'paradigm' over the earlier construct of one-size-fits-all with a fixed technology-base that changes only under duress, an inherently power-dominated model wherein a paradigm is born, grows, becomes dominant, is challenged, and subsequently overturned, invariably dramatically. Against this Kuhnian oldschool dominant paradigm model we can now see at least the semblance of a 


\section{Author}

new form of 'pluralist' paradigmatic framework based on cross-relational connections between multiple paradigmatic formularisms. A paradigm model wherein the formal structures, processes, and thematics are in a state of constant change, or at least readiness to respond to the influence of change drivers such as the continuing growth in capabilities and adaptations of new technology and its use as a set of technological platforms on which new applications are continually being built and distributed.

One message inherent in this argument is that reliance on established practice and technological status quo can be fatal, if not viewed with a healthy scepticism of its longevity and a clear perception of how and when strategic change can and should be introduced. Certainly, all these and more are significant issues to be addressed in the context of future strategic positioning of the manufacturing industry sector, both in the European Union and elsewhere. These approaches represent the onset of a new collaborative-adaptability paradigm for future approaches to the re-development, re-structure and re-enervation of the European industrial manufacturing sector and its potential influence on agility in global manufacturing.

\section{References}

Arnold, H.M. (2003) Technology Shocks: Origins, Managerial Responses, and Firm Performance, Heidelberg: Physica-Verlag.

Beernaert, D (2012) Foreword, in European Commission (2012) ICT and Factories of the Future: Results of the First Two Calls for Proposals, Luxemburg: Publications Office of the European Union. http://cordis.europa.eu/fp7/ict/micronanosystems/docs/ict_and_factories_of_the_future_2012.pdf, Retrieved 30-012013.

Bower, J.L. \& Christensen, C.M. (1995) Disruptive Technologies: Catching the Wave, in Harvard Business Review Jan-Feb 1995 pp. 43-53, Greenwich, CT: Harvard University.

Cetindamar, D. Phaal. R. \& Probert, D. (2010) Technology Management:

Activities and Tools, Basinstoke, Hamps: Palgrave Macmillan.

Champy, J. (1995) Reengineering Management: The Mandate for New

Leadership, London: HarperCollins Publishers.

Checkland, P. (1999) Soft Systems Methodology: A 30-Year Retrospective,

Systems Thinking, Systems Practice, Chichester: John Wiley.

Christensen, C.M. (1997) The Innovator's Dilemma: When New Technologies

Cause Great Firms to Fall, Boston, Mass: Harvard Business School Press.

Christensen, C.M. \& Raynor, M.E. (2003) The Innovator's Solution: Creating and Sustaining Successful Growth, Boston, Mass: Harvard Business School Press.

Christiano, L.J. Eichenbaum, M. \& Vigfusson, R. (2003) What Happens After Technology Shock? NBER Working Paper No 9819, July 2003, National Bureau of Economic Research, www.nber.org/papers/w9819 (15/08/2013)

Coakes, E. (2002) Knowledge Management: A Sociotechnical Perspective, chapter in Coakes, E. Willis, D. \& Clarke, S. Eds. (2002) Knowledge Management in the Socio Technical World: The Graffiti Continues, London: Springer-Verlag.

Coakes, E. \& Clarke, S. (2011) An Introduction to Communities of Practice, in Schwartz. D. \& Te'eni, D. (2011) Encyclopedia of Knowledge Management, $2^{\text {nd }}$ Ed., Chapter 46, pp.482-488, IGI Global. 
Title

Constant, E.W. (1984) as attributed in Gutting, G. (1984) Paradigms, Revolutions, and Technology, chapter in Lauden, R. Ed., (1984) The Nature of Technological Knowledge: Are Models of Scientific Change Relevant? Dordrecht: D. Reidel Publishing Company.

D'Aveni, R.A. \& Gunther, R.E. (1995) Hyper-competitive Rivalries: Competing in Highly Dynamic Environments, New York: Free Press.

Dedola, L. \& Neri, S. (2006) What Does a Technology Shock Do? A VAR Analysis with Model-based Sign Restrictions, Working Paper Series No 705 Dec 2006, Frankfurt: European Central Bank, www.ecb.europa.eu/pub/pdf/scpwps/ecbwp705.pdf (15/08/2013)

Department of Business and Innovation (2011) A More Competitive Manufacturing Industry: New Directions for Industry Policy and Manufacturing, Melbourne: Victorian State Government.

DIISRTE (2012) Prime Minister's Manufacturing Taskforce: Report of the NonGovernment Members, Canberra: Commonwealth of Australia.

Dosi, G. (1982) Technological Paradigms and Technological Trajectories, Research Policy 11 (3) pp. 147-162.

European Commission (2012) ICT and Factories of the Future: Results of the First Two Calls for Proposals, Luxemburg: Publications Office of the European Union. http://cordis.europa.eu/fp7/ict/micro-

nanosystems/docs/ict_and_factories_of_the_future_2012.pdf, Retrieved 30-012013.

Fifth BRICS Summit 2013 (2013) Fifth BRICS Summit Durban South Africa 2013, http//www.brics5.co.za. Retrieved 2013-01-30.

Geels, F.W. (2005) Technological Transitions and System Innovations, Cheltenham: Edward Elgar Publishing.

Geels, F.W. \& Schot, J. (2007) Typology of Sociotechnical Transition Pathways, Research Policy, 36 (2007), pp. 399-417.

http://community.eldis.org/.5ad501d7/Geels\%20and\%20Schot\%20RP\%202007 \%20pathways.pdf (16/08/2013)

Hamel, G. \& Prahalad, C.K. (1990) The Core Competence of the Corporation, Harvard Business Review, May/June90, Vol.68, Issue 3, pp.79-91.

Hamel, G. \& Prahalad, C.K. (1994) Competing for the Future, Boston, Mass:

Harvard Business School Press.

Hammer, M. (1996) Beyond Reengineering: How the Process-centred

Organization is Changing our Work and our Lives, New York: HarperBusiness.

Hammer, M. \& Champy, J. (1993) Re-engineering the Corporation: A Manifesto for Business Revolution, New York: HarperBusiness.

Hernáez, O.R. \& Campos, E.B. (2011) Handbook of Research on Communities of Practice for Organizational Management and Networking: Methodologies for Competitive Advantage, Hershey, PA: Business Science Reference.

Hitt, M.A. Ireland, R.D. \& Hoskisson, R.E. (2011) Strategic Management: Competitiveness \& Globalization $9^{\text {th }}$ Ed., Mason $\mathrm{OH}$ : South-Western CENGAGE Learning.

Johnson, G. Whittington, R. \& Scholes, K. (2011) Exploring Strategy $9^{\text {th }}$ Ed., Harlow: Pearson Education Limited.

Kim, W.C. \& Mauborgne, R. (2004) Blue Ocean Strategy, Harvard Business Review, Oct, 2004, Vol.82(10), pp.76-83. 
Author

Kim, W.C. \& Mauborgne, R. (2005) Blue Ocean Strategy: How to create uncontested market space and make the competition irrelevant, Boston: Harvard Business School Press.

Kuhn, T. (1962) The Structure of Scientific Revolutions, Chicago: University of Chicago Press.

Lencioni, P. (2006) Silos, Politics and Turf Wars: A Leadership Fable about Destroying the Barriers that Turn Colleagues into Competitors, San Francisco, CA: Joffey-Bass.

McGrath, R.G. (2013) The End of Competitive Advantage: How to Keep Your Stragegy Moving as Fast as Your Business, Boston: Harvard Business School Publishing.

Nalebuff, B.J.. \& Brandenburger, A.M. (1997) Coopetition: Competitive and Cooperative Business Strategies for the Digital Economy, Strategy and Leadership, Nov-Dec, 1997, Vol. 25, Issue 6, p.28. Academic OneFile. Web. $15 / 08 / 2013$.

Nonaka, I. \& Teece, D.J. (2001) Managing Industrial Knowledge: Creation, Transfer and Utilization, Thousand Oaks, Ca: SAGE.

Porter, M.E. (1979) How Competitive Forces Shape Strategy, Harvard Business

Review 57, No.2 (March-April 1979): pp. 137-145.

Porter, M.E. (1980) Competitive Strategy, New York: The Free Press.

Porter, M.E. (1985) Competitive Advantage, New York: The Free Press.

Rogers, E. (2003) Diffusion of Innovations $5^{\text {th }}$ Ed. New York: Free Press.

Schumpeter, J. (1950) Capitalism, Socialism and Democracy, $3^{\text {rd }}$ Ed., New York: Harper \& Rowe.

Smith, A. (1776) An Inquiry into the Nature and Causes of the Wealth of Nations, London: Strahan \& Cadell.

Tidd, J. \& Bessant, J. (2013) Managing Innovation: Integrating Technological, Market and Organizational Change $5^{\text {th }}$ Ed., Chichester: John Wiley \& Sons. Toffler, A. (1985) The Adaptive Corporation, London: McGraw-Hill Book Company.

Trappey, A. \& Trappey, C. (2010) Advances in aligning knowledge systems, improving business logistics, driving innovation and adapting customer centric services, Expert Systems with Applications, Vol.37, Issue 11, Nov 2010, pp.7297-7298, Elsevier.

Turnbull, D. (1991) Technoscience Worlds, Geelong: Deakin University. White, A. \& Bessant, J. (2007) Managerial Responses to Cognitive Dissonance: Causes of the Mismanagement of Discontinuous Technological Innovations, in Hashem Sherif, M \& Khalil, T. (Eds.) (2007) Management of Technology: New Directions in Technology Management, Kidlington Oxon: Elsevior.

Wray, F (Ed.) (2012) ICT Innovation for the Factories of the Future: Report from the Workshop on 'ICT Innovation for the factories of the Future' $10^{\text {th }}$ July 2012, Brussels: European Commission, http: //cordis.europa.ey/fp7/ict/micronanosystems/docs/report_from_workshop_on_ict_innovation_for_the_factories _of_the_future.pdf, Retrieved 2013-01-30. 


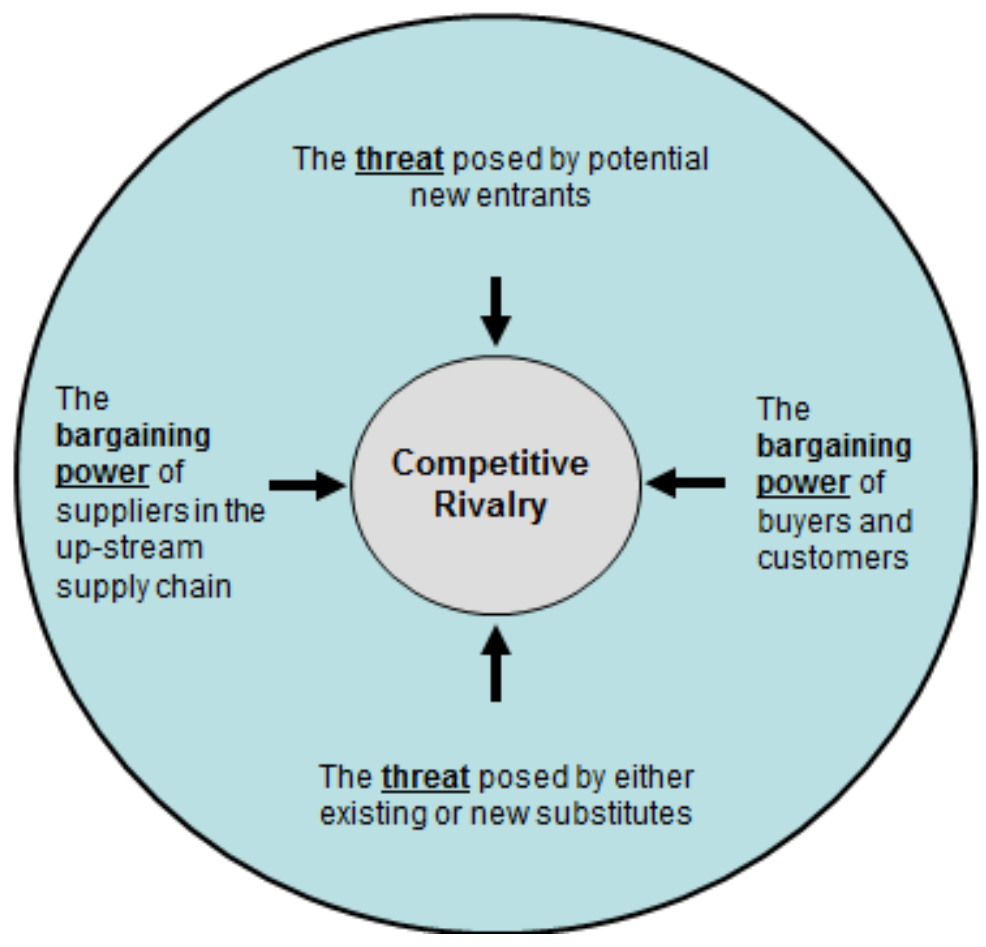

Figure 1. Porter's Five Forces Analysis (Adapted from Porter, 1980) 


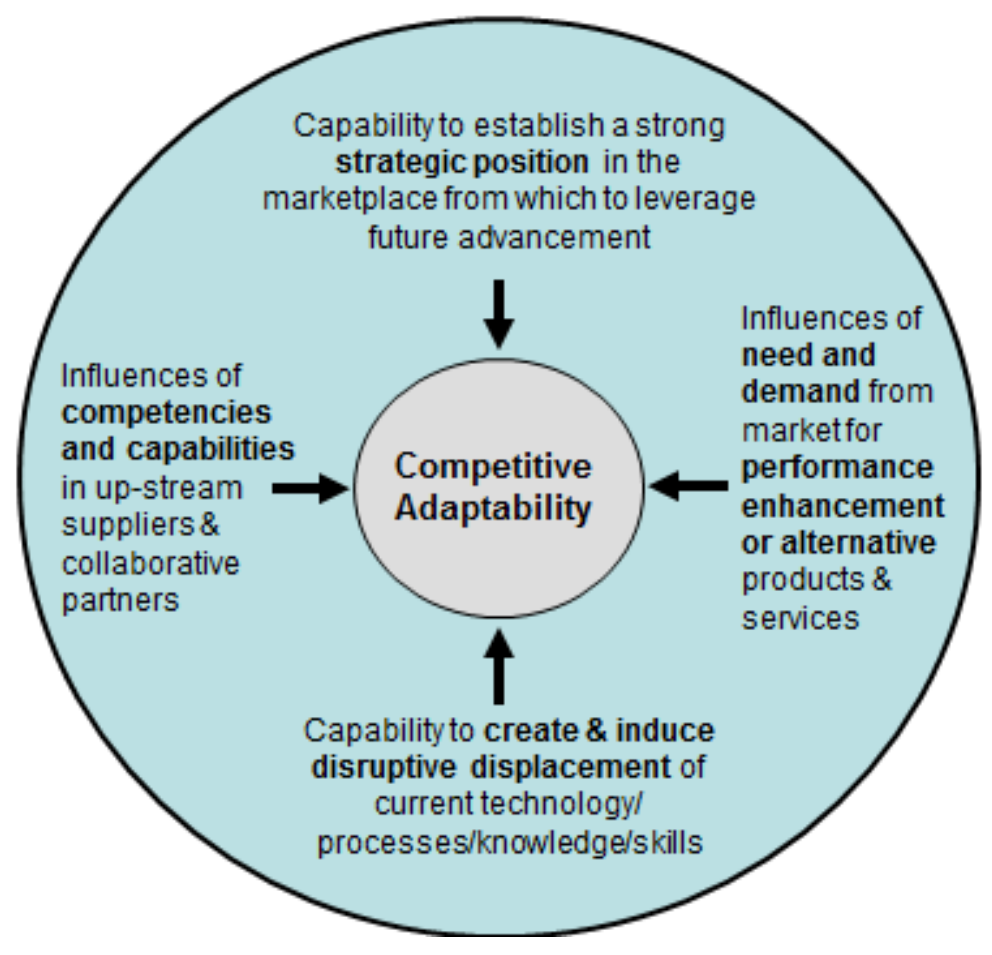

Figure 2. Five-Influences Competitive Adaptability Analysis Model 